\title{
Anti-Mullerian Hormone: Establishing the Ovarian Reserve Range with Age in Rivers State Women, Niger Delta Region of Nigeria
}

\author{
F. C. Ezeiruaku*, C. L. Ezeani \\ Department of Medical Laboratory Science, Faculty of Basic Medical Sciences, College of Health Sciences, Niger Delta University, \\ Wilberforce Island, Nigeria \\ Email: *feddyezeh@yahoo.com
}

How to cite this paper: Ezeiruaku, F.C. and Ezeani, C.L. (2018) Anti-Mullerian Hormone: Establishing the Ovarian Reserve Range with Age in Rivers State Women, Niger Delta Region of Nigeria. Open Journal of Endocrine and Metabolic Diseases, 8, 167-175.

https://doi.org/10.4236/ojemd.2018.89017

Received: August 28, 2018

Accepted: September 24, 2018

Published: September 27, 2018

Copyright $\odot 2018$ by author(s) and Scientific Research Publishing Inc. This work is licensed under the Creative Commons Attribution International License (CC BY 4.0).

http://creativecommons.org/licenses/by/4.0/
Abstract
Background: The measurement of circulating anti-Mullerian hormone (AMH) in the plasma of adult women has been used as a tool in the assessment of ovarian reserve. This is based on its ability to reflect the number of growing follicles in the ovaries and knowing the level of $A M H$ in a woman's blood is generally a good indicator of her ovarian reserve and this can be achieved by making reference to a decision values. Objective: The purpose of this study was to measure the level of this hormone in normal, apparently healthy subjects in Rivers State, Nigeria with respect to age. The percentage of women, at their reproductive age with infertility problems in the state is in the increase and the essence was to establish a reference range for the hormone because of its clinical application in women fertility. Materials/method: A total of one thousand and sixty two apparently healthy women divided into four age groups were recruited for this study; this comprised of 300 each in age group of $20-30,31-40,41-50$ respectively and 162 in 51 - 60 years age group from May 2014 to June 2017. They were randomly selected after filling a questionnaire form that has the information of age, tribe, last date of menses and whether on medication for any infertility problems. Excluded from the study were subjects identified with different endocrine dysfunction and/or on drugs for different types of anovulatory dysfunction. The Enzyme linked Immunoassay method was used in the measurement of the AMH. Results: The result from the measurement of plasma $\mathrm{AMH}$ levels showed a Mean \pm SD value of $3.193 \pm 0.943,1.644 \pm 0.691,0.516 \pm 0.276$ and $0.135 \pm$ $0.081 \mathrm{ng} / \mathrm{ml}$ respectively for the $1^{\text {st }}, 2^{\text {nd }}, 3^{\text {rd }}$ and $4^{\text {th }}$ age groups respectively. The mean value for the AMH decreases with increasing age and was statistically significant at the different age group levels $(\mathrm{P}<0.05)$. The distribution pattern of the $\mathrm{AMH}$, showed that a greater percentage of the women, about 
$46 \%$, in age group 41 - 50 and 51 - 60 had a significant reduced level of the hormone from the group mean value, when compared with age group $20-30$ and 31 - 40 years with about 15\%. Conclusion: The reference, established range for the $\mathrm{AMH}$ (that is, 95\% prediction interval), with respect to age in Rivers State women of Niger Delta region, Nigeria is as follows: -2.250 4.136; $0.953-2.350 ; 0.240-0.792$ and $0.054-0.216$ respectively for the age groups. This study summarizes the findings concerning $\mathrm{AMH}$ and its role as a marker for the quantitative aspect of ovarian reserve, ovarian aging, as well as ovarian dysfunction in this region of the country.

\section{Keywords}

Anti-Mullerian Hormone, Ovary, Reserve, Follicles, Fertility, Anovulatory

\section{Introduction}

The anti-Mullerian hormone $(\mathrm{AMH})$ in females is a glycoprotein produced by the granulosa cells of the antral follicles [1] with major function in growth differentiation and folliculogenesis [2].

The AMH secreted by antral follicles is most often used as a clinical biomarker for ovariian reserve in infertility diagnosis and management [3] [4].

The AMH also is used in detection of premature ovarian aging and serves as a predictor of ovarian responsiveness in ovulation induction and in vitro fertilization [5] [6]. The other uses of $\mathrm{AMH}$ in females may include the production of hyper-stimulation syndrome [7] [8], ovarian function pathology in an infertility setting [6] and detecting post chemotherapy or surgical damage to the ovarian reserve and assessing the need for fertility-preservation strategies [9].

The measurement of AMH in women may help to simplify the World Health Organisation (WHO) classification of anovulation [4] [10]. The class one has to do with hypogonadotropic hypogonadal anovulation (hypothalamic amenorrhea), the class two with Normogonadotropic normoestrogenic anovulation and class three with Hypergonadotropic hypoestrogenic anovulation. Studies has shown that clinical applicability of serum AMH as a diagnostic tool to differentiate between the different classes of anovulatory dysfunction seems to be limited to the production of hypergonadotropic anovulation [4] while others suggest that serum AMH level was associated with abnormal follicular development and would be an effective measurement for ovulatory dysfunction of sterile female [11].

The percentage of women delaying child bearing in Rivers State continues to increase and the demand for an accurate assessment of ovarian reserve has grown. This is because more incidence of ovulatory dysfunction was found in women under reproductive age [12]. Different approaches by physicians have been applied to examine the cause of the ovulatory dysfunction [13] but a reliable validated diagnostic examination is desired worldwide. 
The anti-Mullerian hormone produced by the granulosa cells of small antral and pre-antral follicles and reflects the size of the pool of these follicles [14] declines with age but remains stable during the menstrual cycle allowing its determination at random [15]. Establishing the AMH level in infertility females is crucial to categorize them as ovulation after treatment with different ovulation stimulants [16]. Establishing a reference in this environment is therefore important for a proper clinical judgement and management of female infertility.

\section{Materials/Methods}

\subsection{Study Area}

The study establishing the reference range for the anti-Mullerian hormone was carried out in Port Harcourt, Rivers State and its environs, Niger Delta Region of Nigeria. Port Harcourt, capital city of Rivers State has a population of about $1,382,592$ inhabitants [17] and 538,558 are females. The majority of the females are civil servants and peasant business women.

\subsection{Study Subjects}

The totals of one thousand and sixty two apparently healthy fertile and sub fertile subjects (advanced in age) between the ages of 20 to 60 were recruited for the study. Four different groups of 20 - 30, 31 - 40, $41-50$ and 51 - 60 years with 300 subjects each, except 51 - 60 years group with 162 subjects. All subjects were recruited between May 2014 and June 2017 from Port Harcourt and it's environ of Rivers State, Nigeria. They were randomly selected after filling a questionnaire form that has the information of age, tribe, last date of menses, whether on medication for any infertility problems. Excluded from the study were subjects identified with different endocrine dysfunction, increased BMI, pregnancy and or on drugs for different types of anovulatory dysfunction [18]. The essence and details of the study were explained to the subjects and informed consent was obtained from them before sample collection. Ethical approval was gotten from the human ethical committee of the University for this Study.

\subsection{Sampling Method}

To achieve this reference range establishment, a random sampling of the different women from the population was used. This took into consideration the age of the subjects, excluding those that have different endocrine dysfunctions and women with infertility as established [19] [20]. The apparently healthy subjects were selected for the study and with a method that has been established to give a precise range of results in hormonal assay [21].

\subsection{Study Assay}

Anti-Mullerian hormone serum samples were collected in a $5 \mathrm{ml}$ serum separator tube and processed within 2 hours to avoid Red blood cell haemolysis. Samples were centrifuged for 10 minutes at $3000 \mathrm{rpm}$ at room temperature. The se- 
rum is transferred into a $1 \mathrm{ml}$ plain tube and stored frozen at $20^{\circ} \mathrm{C}$. The $A M H$ levels were determined using the Enzyme Linked Immunosorbent Assay (ELISA) method [21]. Specifically, Human AMH ELISA Kit from Elabscience USA was used for the determination of serum AMH levels. This ELISA Kit uses the Sandwish ELISA principle and the Biotech plate reader was used to read the samples at $450 \mathrm{~nm}$ [22].

\subsection{Statistical Analysis}

The data are expressed as mean \pm standard deviation, standard error of mean and normal ranges. Correlation between the groups studied was tested using the regression analysis. The results obtained from this were subjected to statistical analysis using standard computerized analysis tool of ANOVA: two factors without replication and standard t-test: pair two samples for mean. 95\% confidence level $(P<0.05)$ were used and considered significant.

\section{Results}

The result of the study on the establishment of the ant-Mullerian hormone reference range in Portharcourt is as presented in the tables and figures below. With the method used, the result has shown that the AMH as a measure of ovarian reserve decreases with aging and at menopause, the levels get undetected. The ranges for each group level were statistically significant $(P<0.05)$ from each other.

\section{Discussions}

Screening for ovarian reserve is a fundamental part of fertility assessment and management. Measuring the AMH has emerged as a key marker of ovarian reserve [23] due to its ability to reflect the number of small antral and preantral follicles present in the ovaries. At birth, the female has the maximum number of ovarian follicles which decline with time until the eggs are depleted at menopause. The reproductive potential of a woman in terms of fertility therefore is associated to her current supply of eggs. A woman expects an earlier menopause if at certain age, the level of AMH is low and vice versa when the AMH level is high. At different ovarian dysfunctions, the AMH level as a predictor of ovarian reserve or fertility is not attainable; therefore ovary does not age as predicted. This study that established the reference range in this part of the world will help the physician to make reference and interpret results of varying women that wants to solve different fertility problems.

From the results of this study (Table 1 and Table 2), the mean AMH level of $3.193 \mathrm{ng} / \mathrm{ml}$ at early average age of 25 years depleted significantly $(\mathrm{P}<0.05)$ to $0.135 \mathrm{ng} / \mathrm{ml}$ at menopause age of 55 years with a range of $2.250-4.136$ and 0.054 0.216 respectively. The median AMH quartile range value of 3.12 for age group 20 - 30 years and 0.13 for age group $51-60$ years (Table 3 ) has shown how undetectable the serum AMH at this level and are statistically significant $(\mathrm{P}<0.05)$. 
Table 1. Comparison of anti-Mullerian hormone ( $\mathrm{ng} / \mathrm{ml})$ by age group.

\begin{tabular}{ccccccc}
\hline $\begin{array}{c}\text { Age Group } \\
\text { (Years) }\end{array}$ & $\mathrm{N}$ & Mean & SEM & $\begin{array}{c}\text { Lower } \\
95 \%\end{array}$ & $\begin{array}{c}\text { Upper } \\
95 \%\end{array}$ & P-Value \\
\hline $20-30$ & 300 & $3.193^{\mathrm{a}}$ & 0.063 & 3.169 & 3.418 & \\
$31-40$ & 300 & $1.644^{\mathrm{b}}$ & 0.037 & 1.571 & 1.718 & \\
$41-50$ & 300 & $0.516^{\mathrm{c}}$ & 0.017 & 0.482 & 0.549 & \\
$51-60$ & 162 & $0.135^{\mathrm{d}}$ & 0.008 & 0.129 & 0.162 & $<0.0001^{* * * *}$ \\
\hline
\end{tabular}

SEM: Standard error of mean; Means \pm SEM with different superscripts are significantly different at $\mathrm{P}<$ 0.05. Significance Level: ${ }^{* * *}=\mathrm{P}<0.0001$.

Table 2. Comparison of anti-Mullerian hormone ( $\mathrm{ng} / \mathrm{ml})$ by age group.

\begin{tabular}{cccccc}
\hline $\begin{array}{c}\text { Age Group } \\
\text { (Years) }\end{array}$ & $\mathrm{N}$ & Mean & SD & Reference Range & P-Value \\
\hline $20-30$ & 300 & $3.193^{\mathrm{a}}$ & 0.943 & $2.250-4.136$ & \\
$31-40$ & 300 & $1.644^{\mathrm{b}}$ & 0.691 & $0.953-2.335$ & \\
$41-50$ & 300 & $0.516^{\mathrm{c}}$ & 0.276 & $0.240-0.792$ & \\
$51-60$ & 162 & $0.135^{\mathrm{d}}$ & 0.081 & $0.054-0.216$ & $<0.0001^{\star * *}$ \\
\hline
\end{tabular}

SD: Standard deviation; Means \pm SD with different superscripts are significantly different at $\mathrm{P}<0.05$. Significance Level: ${ }^{* * * *}=\mathrm{P}<0.0001$.

Table 3. Quantiles of anti-Mullerian hormone ( $\mathrm{ng} / \mathrm{ml}$ ) by age group (years).

\begin{tabular}{cccccc}
\hline \multirow{2}{*}{ Proportion } & \multirow{2}{*}{ Range } & \multicolumn{4}{c}{ Age Group (Years) } \\
\cline { 3 - 6 } & & $20-30^{\mathrm{a}}$ & $31-40^{\mathrm{b}}$ & $41-50^{\mathrm{c}}$ & $51-60^{\mathrm{d}}$ \\
\hline $100.0 \%$ & Maximum & 6.36 & 3.78 & 2.40 & 0.90 \\
$99.5 \%$ & & 6.36 & 3.78 & 2.40 & 0.90 \\
$97.5 \%$ & 6.04 & 3.09 & 1.15 & 0.30 \\
$90.0 \%$ & & 4.82 & 2.6 & 0.87 & 0.24 \\
$75.0 \%$ & Quartile & 3.82 & 2.00 & 0.67 & 0.19 \\
$50.0 \%$ & Median & 3.12 & 1.55 & 0.435 & 0.13 \\
$25.0 \%$ & Quartile & 2.57 & 1.13 & 0.3 & 0.08 \\
$10.0 \%$ & & 1.91 & 0.9 & 0.222 & 0.06 \\
$2.5 \%$ & & 1.59 & 0.68 & 0.16 & 0.03 \\
$0.5 \%$ & & 1.38 & 0.59 & 0.14 & 0.02 \\
$0.0 \%$ & & 1.38 & 0.59 & 0.14 & 0.02 \\
\hline
\end{tabular}

${ }_{\text {a,b,c,d }}$ Significantly different at $\mathrm{P}<0.05$.

The distribution pattern of the AMH (Figure 1 and Figure 2), showed that a greater percentage of the women, about $46 \%$, in age group $41-50$ and $51-60$ had a significant reduced level of the hormone from the group mean value, when compared with age group 20 - 30 and 31 - 40 years with about $15 \%$. This means that women who delay pregnancy run the risk of developing age related infertility as their ovarian reserve declines. The result of this study will guide women regarding the status of their biological clock and may reduce the need for fertility 


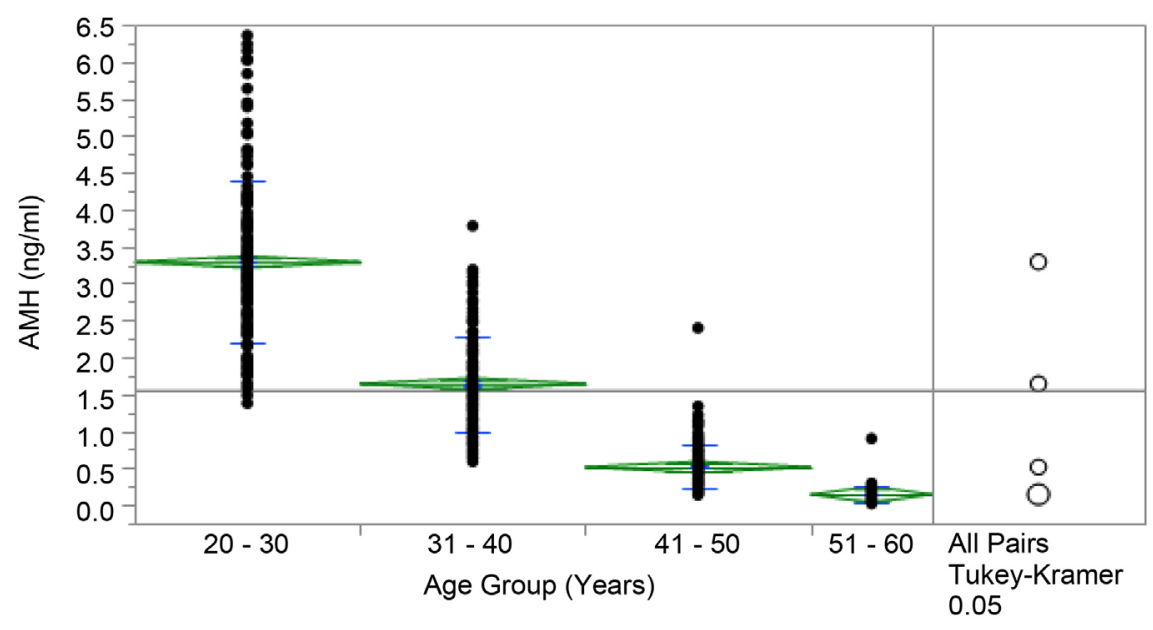

Figure 1. Distribution of anti-Mullerian hormone (ng/ml) by age group (years).

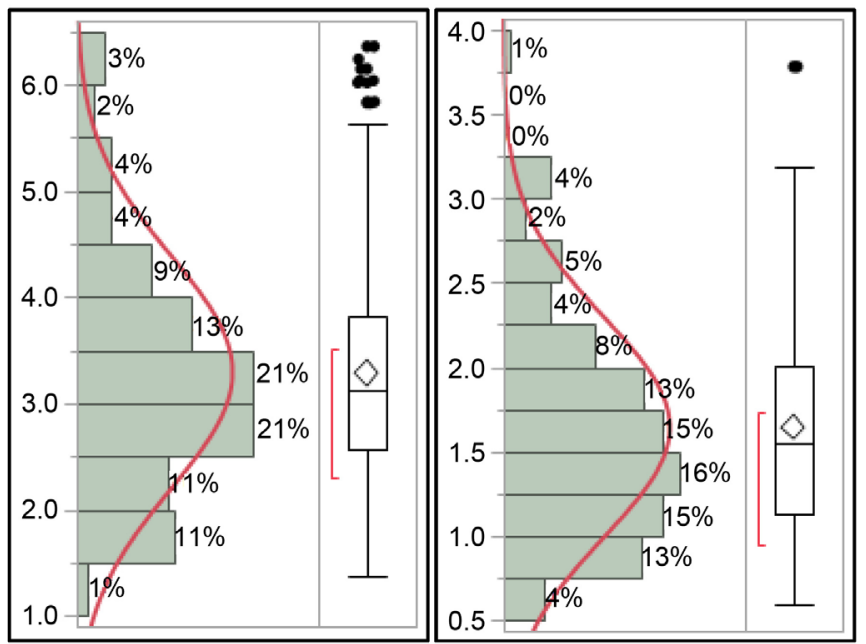

(a)

(b)

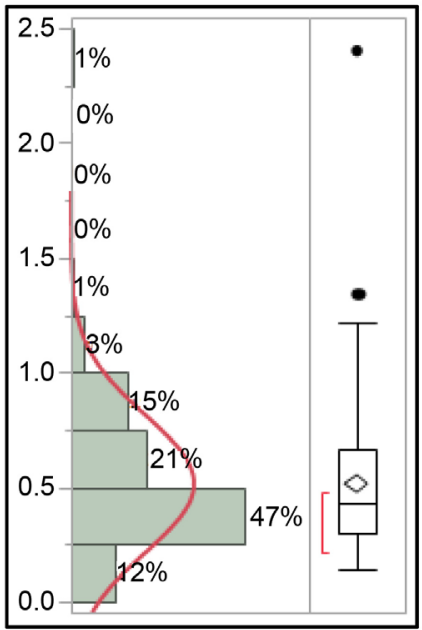

(c)

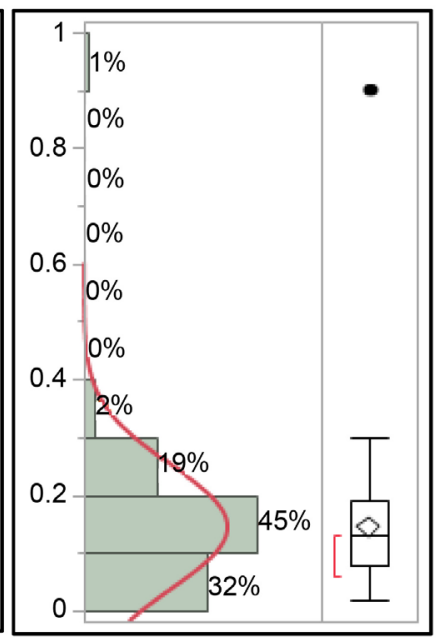

(d)

Figure 2. Distribution of anti-Mullerian hormone $(\mathrm{ng} / \mathrm{ml})$ by age group (years). (a) 20 - 30 Years; (b) 31 - 40 Years; (c) 41 - 50 Years; (d) 51 - 60 Years. 
treatments on these patients. The findings of this study are in line with some earlier studies [3] [4] [24] [25] [26] and research continues to demonstrate the important role of $\mathrm{AMH}$ in assessing ovarian reserve or predict response to ovarian stimulation in assisted reproductive treatments.

\section{Conclusion}

The levels of Anti-Mullerian hormone, known to predict the ovarian reserve fluctuate only minimally throughout the menstrual cycle, but decline and deplete with aging. The determination of the serum AMH was done using enzyme Linked Immunosorbent Assay (ELISA). The reference, established range for the AMH (that is, 95\% prediction interval) with respect to age in Rivers State women of Niger Delta region, Nigeria is as follows: $-2.250-4.136 ; 0.953-2.350$; $0.240-0.792$ and $0.054-0.216$ respectively for the age groups of $20-30,31-40$, 41 - 50 and 51 - 60 years respectively. This study summarizes the findings concerning $\mathrm{AMH}$ and its role as a marker for the quantitative aspect of ovarian reserve, ovarian aging, as well as ovarian dysfunction in this region of the country.

\section{Limitations about the Study}

1) Getting the consent of the identified subjects, as many of them are not literate enough to understand the reasons for the study.

2) The cost of AMH kit that limits the sampling size.

\section{Acknowledgements}

This is to acknowledge the diagnostic and financial support in part by De-integrated Medical diagnostic and Research Centre Port-Harcourt, Nigeria.

\section{Conflicts of Interest}

The authors declare no conflicts of interest regarding the publication of this paper.

\section{References}

[1] Rzeszowska, M., Leszcz, A., Putowski, L., Halabis, M., Tkaczuk-Wilach, J., Kotarski, J. and Polak, G. (2016) Anti-Mullerian Hormone: Structure Properties and Appliance. Ginekologia Polska, 87, 669-674. https://doi.org/10.5603/GP.2016.0064

[2] Vigier, B., Picard, J.Y., Tran, D., et al. (1984) Production of Anti-Mullerian Hormone: Another Homology between Sertoli and Granulosa Cells. Endocrinology, 114, 1315-1320. https://doi.org/10.1210/endo-114-4-1315

[3] Van Rooij, I.A., Broekmans, F.J., Scheffer, G.J., et al. (2005) Serum Anti-Mullerian Hormone Levels Best Reflect the Reproductive Decline with Age in Normal Women with Proven Fertility; Longitudinal Study. Fertility Sterility, 83, 979-987. https://doi.org/10.1016/j.fertnstert.2004.11.029

[4] Lie Fong, S., Schipper, I., Valkenburg, O., et al. (2015) The Role of Anti-Mullerian Hormone in the Classification of Anovulatory Infertility. European Journal of $\mathrm{Ob}$ stetrics \& Gynecology and Reproductive Biology, 186, 75-79. https://doi.org/10.1016/j.ejogrb.2015.01.007 
[5] Dewily, D., Anderson, C.Y., Balen, A., et al. (2014) The Physiology and Clinical Utility of AMH in Women. Human Reproduction Update, 20, 370-385. https://doi.org/10.1093/humupd/dmt062

[6] Gnoth, C., Schuring, A.N., Friol, K., Tigges, J., Mallmann, P. and Godebardt, E. (2008) Relevance of Anti-Mullerian Hormone Measurement in a Routine IVF Program. Human Reproduction, 23, 1359-1365. https://doi.org/10.1093/humrep/den108

[7] Van Rooij, I.A., Broekmans, F.J., te Velde, E.R., et al. (2002) Serum Anti-Mullerian Hormone Levels: A Novel Measure of Ovarian Reserve. Human Reproduction, 17, 3065-3071. https://doi.org/10.1093/humrep/17.12.3065

[8] Dabkowska-Hue, A., Lemm, M., Sikora, J., et al. (2013) Anti-Mullerian Hormone Dynamics during Ovulation Induction Treatment with Recombinant Follicle Stimulating Hormone in Women with Polycystic Ovary Syndrome. Endokrynologia Polska, 64, 203-207.

[9] Dunlop, C.E. and Anderson, R.A. (2015) Uses of Anti-Mullerian Hormone (AMH) Measurement before and after Cancer Treatment in Women. Maturitas, 80, 245-250. https://doi.org/10.1016/j.maturitas.2014.12.005

[10] WHO (2005) WHO Classification of anovulation. International Congress Series 1279, 3-9. https://doi.org/10.1016/j.ics.2004.12.028

[11] Liu, H. and Hong, L. (2017) Anti-Mullerian Hormone as Examination for Ovulatory Dysfunction of Female. Biomedical Research, 28, 55-64.

[12] Toong, Y.L., Soyeon, A., Jung, R.L., et al. (2017) Reference Values for the Revised Anti-Mullerian Hormone Generation II Assay: Infertile Population-Based Study. Journal of Korean Medical Sciences, 32, 825-829. https://doi.org/10.3346/jkms.2017.32.5.825

[13] Parahulera, N., Pahlivanov, B., Orbecova, M., Uchikova, E. and Ivancheva, H. (2014) Anti Mullerian Hormone in the Major Phenotypes of Polycytic Ovary Syndrome. Akush Ginekol (Sofiia), 53, 22-27.

[14] Fleming, R., Seifer, D.B., Frattarelli, J.L. and Ruman, J. (2015) Assessing Ovarian Response: Antral Follicle Count versus Anti-Mullerian Hormone. Reproductive BioMedicine Online, 31, 486-496. https://doi.org/10.1016/j.rbmo.2015.06.015

[15] Sonigo, C., Simon, C. and Boubaya, M. (2016) What Threshold Values of Antral Follicle Count and Serum AMH Levels Should Be Considered for Oocyte Cryo-Preservation after in Vitro Maturation. Human Reproduction, 31, 1493-1500. https://doi.org/10.1093/humrep/dew102

[16] Ellakwa, H.E., Sanad, Z.F., Hamza, H.A., Emara, M.A. and Elsayed, M.A. (2016) Predictions of Patients Responses to Ovulation Induction with Clomiphene Citrate in Patients with Polycystic Ovary Syndrome Experiencing Infertility. International Journal of Gynecology \& Obstetrics, 133, 59-63. https://doi.org/10.1016/j.ijgo.2015.09.008

[17] National Population Commission of Nigeria (2006) Population and Housing Census. Federal Ministry of Internal Affairs, Volume 5.

[18] Ezeiruaku, F.C., Baro, J.O. and Okeke, C.U. (2017) Establishment of Reference Values for Serum Dehydroepiandrosterone-Sulphate (DHEA-S) in Healthy Adults in Yenagoa, Bayelsa State, Nigeria. Nigerian Biomedical Science Journal, 13, 12-17.

[19] Ceriotti, F., Hinzmann, R. and Panteghini, M. (2009) Reference Intervals: The Way Forward. Annual Clinical Biochemistry, 46, 8-17. https://doi.org/10.1258/acb.2008.008170 
[20] Solberg, H.E. and PetitClerc, C. (1988) Approved Recommendation (1988) on the Theory of Reference Values, Part 3. Preparation of Individual and Collection of Specimens for the Production of Reference Values. Clinica Chimica Acta, 177, S3-S11.

[21] Amballi, A.A., Dada, O.A., Adeleye, A.O. and Jide, S. (2007) Evaluation of the Determination of Reference Ranges for Reproductive Hormones (Prolactin, LH, FSH, and Testosterone) Using Enzyme Immuno Assay Method. Scientific Research and Essay, 2, 135-138.

[22] Erol, O., Parlak, M., Ethjda, H.Y., et al. (2016) Serum AMH Levels in Euthyroid Adolescent Girls with Hashimoto's Thyroiditis. Relationship to Antioxidant Status. The European Journal of Obstetrics \& Gynecology and Reproductive Biology, 203, 204-209. https://doi.org/10.1016/j.ejogrb.2016.06.002

[23] La Marce, A., Sighinolfi, G., Radi, D., et al. (2010) Anti-Mullerian Hormone (AMH) as a Predictive Marker in Assisted Reproductive Technology (ART). Human Reproduction Update, 16, 113-130. https://doi.org/10.1093/humupd/dmp036

[24] Lee, J.Y., Jee, B.C., Le, J.R., et al. (2012) Age-Related Distributions of Anti-Mullerian Hormone Level and Anti-Mullerian Hormone Models. Acta Obstetricia et Gynecologica Scandinavica, 91, 970-975.

https://doi.org/10.1111/j.1600-0412.2012.01448.x

[25] La Marca, A., Stabice, G., Artenisio, A.C. and Volpe, A. (2006) Serum Anti-Mullerian Hormone throughout the Human Menstrual Cycle. Human Reproduction, 21, 3103-3107. https://doi.org/10.1093/humrep/del291

[26] Bozkurt, B., Erddem, M. and Mutlu, M.F. (2016) Comparison of Age Related Changes in Anti-Mullerian Hormone Levels and Other Ovarian Reserve Lists between Healthy Fertile and Infertile Population. Human Fertility, 19, 192-198. https://doi.org/10.1080/14647273.2016.1217431 